
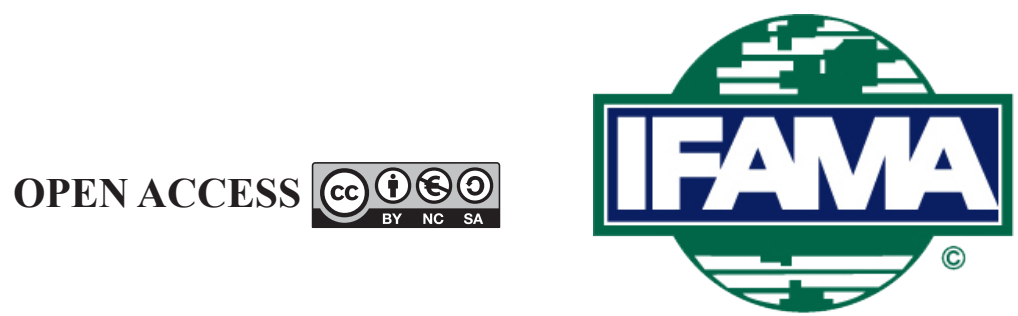

International Food and Agribusiness Management Review

Volume 23, Issue 4, 2020; DOI: 10.22434/IFAMR2020.0008

Received: 20 February 2019 / Accepted: 25 June 2020

\title{
Factors influencing German farmer's decision to grow alley cropping systems as ecological focus areas: a regression analysis \\ RESEARCH ARTICLE
}

Lara Beer ${ }^{\oplus a}$ and Ludwig Theuvsen ${ }^{\mathrm{b}}$

${ }^{a}$ Dr, ${ }^{b}$ Professor Dr, Agribusiness Management, Department of Agricultural Economics and Rural Development, University of Goettingen, Platz der Goettinger Sieben 5, 37073 Goettingen, Germany

\begin{abstract}
The cultivation of alley cropping agricultural wood is an opportunity to comply with the greening requirements of the common agricultural policy (CAP; 2014-2020), but farmers are not permitted to display the whole alley cropping system (ACS) as ecological focus area (EFA) in Germany. They can display the agricultural wood stripes separately as EFA instead. The willingness of farmers is of key importance for a successful establishment, but, so far, the acceptance of this greening measure is extremely low. The aim of this paper is therefore to point out factors which have linkages to the acceptance of ACS as EFAs by conducting an online survey among German conventional farmers. The results of the regression analysis show that factors such as attitude towards agricultural wood, level of professional education, location and social environment affect the acceptance of ACS as EFA. To conclude, starting points that promote this type of greening measure are identified.
\end{abstract}

Keywords: agricultural wood, alley cropping system, ecological focus area, growing decision, regression JEL code: C38, Q18, D22

(1) Corresponding author: lara.beer90@gmail.com 


\section{Introduction}

Greening was one of the most important changes introduced with the latest reform of the common agricultural policy (CAP) ${ }^{1}$ (European Commission, 2013). The receipt of direct payments is tied to three specific environmental requirements in the current funding period of 2014 to 2020 (SRU, 2013): diversifying crops, maintaining permanent grassland, and dedicating arable land to ecologically beneficial elements. The latter stipulates that farms with at least 15 hectares of arable land must designate a minimum of $5 \%$ of their arable land as ecological focus areas (EFAs) to comply with the greening requirements (BMEL, 2015a). One option for providing EFAs is to plant agricultural wood (BMEL, 2015b). In this connection, agricultural wood refers to the planting of fast-growing tree species such as poplars or willows on land used for agriculture with a maximum rotation period of 20 years (Dziewiaty et al., 2013). Besides the high annual growth in yields, the trees are suitable for coppicing which opens up the possibility of multiple harvesting. The aim of cultivating agricultural wood is generally to produce woodchips for electricity or heat generation (Bärwolff et al., 2013). Agricultural wood can be planted in a variety of ways: the plantation can occur in the form of a short-rotation coppice (SRC) on the entire field or in strips in the form of an alley cropping agroforestry system. Agricultural wood in form of an alley-cropping-system (ACS) can be integrated into particularly adversely shaped sections of field, which enables it to contribute towards the technical improvement of the field and increase machine effectiveness. CAP greening provides farmers with the opportunity to designate these difficult-to-reach field sections with ACS as EFAs. However, ACS in the whole currently are not permitted as EFA in Germany but farmers can display the SRC-stripes of an ACS separately as EFA (BMEL, 2015c). This requires an area of at least 0.3 hectares $^{2}$ for the agricultural wood and the growing of certain tree species. Furthermore, fertilizers and pesticides are prohibited in the claim year (BMEL, 2015b).

In principle, agricultural wood (SRC as well as ACS) offers an array of benefits (for an extensive account, see Drittler and Theuvsen, 2017): for instance, farmers can expand their product range with agricultural wood (Grünewald and Reeg, 2009) and thereby diversify their cultivation structures (Feldwisch, 2011). Particularly in locations with marginal yields, agricultural wood can help to spread risk and reduce income fluctuations (Eichhorn et al., 2006; Wolbert-Haverkamp, 2012). Another advantage of agricultural wood compared to annual crops can be seen in the reinforcement and stabilization of the soil nutrient content which results from the redistribution of nutrients from deeper soil layers (Grünewald and Reeg, 2009) and a reduced leaching of nutrients (Feldwisch, 2011). However, particularly in ACS, competing effects for nutrients or light, in turn, can also rise between the annual crop and the strips of agricultural wood; whereas a loss of yield of the annual crops can only be observed from a tree age of more than 20 years (Bärwolff et al., 2011; DBU, 2010). Moreover, with the effects of year-round ground cover on adjacent areas, agricultural wood is able to help reduce wind and water erosion (Anderson et al., 2009; Feldwisch, 2011; Lamerre et al., 2015). Especially in monotonous, large-scale and extensively cleared farming landscapes, agricultural wood can also enrich the cultivated landscape as a structural element and visually break up the land (BUND, 2010; DLG, 2012), and thereby enhance the overall image of the landscape (Feldwisch, 2011; Nitsch et al., 2016; Rigueiro-Rodríguez et al., 2009; Spiecker et al., 2009). However, it should be ensured that the extent of the agricultural wood area fits into the landscape because oversized SRC or ACS, in turn, can be experienced as disturbing regarding to the recreational function of landscape (Peters, 2012). In addition, various land use requirements (bioenergy source production and foodstuffs) can be satisfied simultaneously with the planting of strips of agricultural wood in particular (Grünewald and Reeg, 2009). The cultivation of agricultural wood can likewise increase the biodiversity on fields (Grünewald and Reeg, 2009; Lamerre et al., 2015; Spiecker et al., 2009; Zehlius-Eckert, 2010) as long as the area is not oversized; too large SRC in turn, can affect the biodiversity negatively (Weih et al., 2003).

\footnotetext{
${ }^{1}$ The present article is part of a project that was granted at a time where it was not yet foreseeable that greening would not be continued in its design in the CAP after 2020. Nevertheless, this article grants important implications in the light of the CAP after 2020 because the requirements of greening will be part of the so-called new conditionality which will remain mandatory for the receipt of direct payments.

${ }^{2}$ However, the CAP allows the governments of the German federal states to lower this minimum size due to regionally different farmland sizes.
} 
The growing of agricultural wood can thus combine the achievement of various goals (Reeg, 2010) and contribute towards more sustainable farming that meets the needs of both the economy and ecology at the same time (Bärwolff et al., 2013; Wirkner, 2012). Nonetheless, German farmers only grow agricultural wood - especially as EFAs - to a very limited extent (around 7,000 hectares of SRCs and ACSs) (BMEL, 2015c, 2016, 2018; Klabunde, 2016), although agricultural wood is a bioenergy source that is accepted by a general public who are aware of the food-or-fuel debate (Henke and Theuvsen, 2014; Herbes et al., 2014; Schaper and Theuvsen, 2006; Zschache et al., 2009) and which is classed as ecologically valuable in various studies (Anderson et al., 2009; Bärwolff et al., 2013; Lamerre et al., 2015).

Various studies on the cultivation of agricultural wood in Europe have already examined the acceptance of SRC (Boll et al., 2015; Glithero et al., 2013; Roos et al., 2000; Skodawessely and Pretzsch, 2009; Warren et al., 2016; Wróbel et al., 2009) and agroforestry systems (Borremans et al., 2016; Pisanelli et al., 2012; Sereke et al., 2016). In contrast, the acceptance of ACS as EFAs has not yet been the subject of scientific study. A rare exception is Beer and Theuvsen (2019) who analyzed farmers' attitudes towards agricultural wood and their willingness to plant ACSs as EFA. This paper takes a broader view and analyses attitudes from a broader angle; therefore, statements on interest and cultivation risks are also included in the analysis. However, although the willingness of farmers to plant ACS is of key importance for the successful establishment of this EFA measure, research is still very scarce. To close this research gap, the aim of this paper is to point out the factors that have a linkage to the willingness of German farmers to grow ACS as EFAs and to identify starting points for promoting the cultivation of ACS as EFAs. The paper is structured as follows: Section 2 describes the status of research on the factors that influence the decisions of farmers and sets forth the hypotheses underlying this investigation. Section 3 is dedicated to an account of the material and methods. The findings are presented in Section 4. The paper closes with a discussion of the findings and several conclusions in Section 5.

\section{Factors influencing the decisions of German farmers}

In theory, a decision is a calculating and goal-oriented action performed by an individual. Decision-makers have at least two possible courses of action to choose from (Pfister et al., 2017). Neurological research has shown that two decision-making systems in different parts of the brain are existing; one part is much more active for decisions that are really contemplated, logical, controlled, and another part that is more active when decisions are made more unconsciously, based on routines (Gold and Shadlen, 2007). In the case of business decisions, it is often assumed for reasons of simplification that they only act rationally in strict pursuit of economic profit maximization. In practice, however, the decision-making process is influenced by non-economic factors in addition to economic factors (Austin et al., 1998; Edwards, 1954; Ilbery, 1978; Kahneman and Tversky, 1979; Simon, 1959; Warren et al., 2016). To summarize these studies: the decision behavior of farming businesses is subject to the influence of operational characteristics, environmental factors and the motives of the decision-makers (Burton, 2004). In the literature, a distinction is therefore drawn between operational and personal factors as well as external factors in the form of the social environment.

\subsection{Operational factors}

Studies on the investment behavior of farmers were also considered in the selection of literature; although agricultural wood is a rather atypical investment, since it is practically arbitrarily divisible, these studies are still able to provide indications of relevant factors. The size of the farm - in the form of the area available - is a variable that determines the decisions of farmers in various respects (Ilbery, 1978). Gardebroek and Oude Lansink (2004) show that the available area of a farm affects the decision of the farm manager to invest in buildings. According to Barham et al. (2004), Granoszewski et al. (2009) as well as Savastano and Scandizzo (2009), a high availability of land or the possibility to procure land promotes investment; the investment thresholds declines as farm size increases. The larger a farm is, the more willing farmers are, for example, to invest in a biogas plant (Granoszewski et al., 2009). Regarding the planting of energy crops, the farm size likewise affects the decision to plant (Breen et al., 2009; Paulrud and Laitila, 2010). In a survey on the 
acceptance of SRC, Roos et al. (2000) determine that the decision on the choice of tree species is influenced by the area of arable land and wooded land available. The proportion of leasehold land and grassland has a negative effect on the decision to plant (Roos et al., 2000). In contrast to the investment in biogas plants (Granoszewski et al., 2009), investment in an SRC negatively correlates with the farm size: according to Neubert et al. (2013), small farms with fewer than 50 hectares consider the possibility of planting SRCs more intensively than large farms with more than 500 hectares. Notwithstanding the discrepancies regarding farm size, Hypothesis 1 is formulated thus:

H1: The smaller the area cultivated by a farm, the more farmers are willing to plant an ACS as EFA.

In the literature, the type of employment of the farm represents another determinant of the decision behavior of farmers. Vollmer et al. (2015) were able to identify the influence of the type of employment 'main occupation' on investment behavior. According to Adesina et al. (2000), part-time farmers invest in an SRC earlier than full-time farmers due to their secured income beyond farming. Consequently, Hypothesis 2 is set down as follows:

H2: Managers of farms operated as part-time employment are more willing to plant an ACS as EFA.

The majority of decisions made by farmers focus on the realization of profits (Swinton et al., 2015). Jonsson et al. (2011) identify economic factors as key determinants in the decision to plant energy crops. According to Granoszewski et al. (2009), a good economic initial situation of the farm has a positive effect on the investment behavior of the farm manager. In particular, the self-assessment of the economic situation and the future viability of the farm determine the decision to invest. Farm managers of successful farms invest more readily in a biogas plant, for example, when they are satisfied with their financial situation (Granoszewski et al., 2011). Accordingly, Hypothesis 3 is formulated:

H3: The more economically advantageously the farm is positioned, the greater the willingness of the farmer to plant an ACS as EFA.

Gardebroek and Oude Lansink (2004) identify the farm location as a factor in the decision to invest in new buildings. The decision to plant SRCs is likewise affected by the geographical location as well as soil conditions (Roos et al., 2000; Wróbel et al., 2009). Skodawessely and Pretzsch (2009) also ascertain that the willingness to plant wood fuel trees is dependent on the location in the form of soil quality and annual rainfall. In light of this, Hypothesis 4 is expressed as follows:

H4: The better the location factors of the farm are, the lower the willingness of the farmer to plant an ACS as EFA.

\subsection{Personal factors}

The age of a farmer is a further determinant of the decision behavior (Ilbery, 1978). Paulrud and Laitila (2010) identify the age of the farmer as being a factor affecting the decision to plant energy crops. The willingness to plant SRCs is also decisively influenced by the age of the farm manager (Roos et al., 2000). Gardebroek and Oude Lansink (2004) find that the willingness to invest in buildings declines with increasing age. Younger farmers accordingly tend to invest earlier than their older occupational peers. Only when the advantages of investment are large enough older farmers are likewise willing to invest (Gardebroek and Oude Lansink, 2004). Wróbel et al. (2009) and Neubert et al. (2013) show that the willingness to plant SRCs falls with increasing age. Accordingly, farmers younger than 40 years of age demonstrate the greatest willingness to plant a SRC. Consequently, Hypothesis 5 is composed:

H5: The older a farmer is, the lower the willingness to plant an ACS as EFA. 
The decision behavior of farmers is also affected by their level of education (Breen et al., 2009; Ilbery 1978). Sauer and Zilberman (2009) show that better-educated managers of dairy farms are more prepared to invest in a new technology; similar results can also be seen in studies for other industry sectors (Heise, 2017; Müller, 2017). Good professional education thereby clearly reduces the investment threshold for farmers (Gardebroek and Oude Lansink, 2004). Moreover, a completed degree increases the probability of choosing the optimal time to invest (Holst et al., 2016). Vollmer et al. (2015) demonstrate that deviations from recommended courses of action - defined on the basis of the real options approach - occur less frequently, the higher the education level of pig farmers is. Against this background, Hypothesis 6 is drawn:

H6: A higher level of professional education positively influences the decision of farmers to plant an ACS as EFA.

The attitude of a person relates to his or her behavioral intention (Fishbein and Ajzen, 1975). The action of farmers is influenced by attitudes, personal characteristics and aims (Willock et al., 1999). Borris and Maart-Nölck (2013) show that personal attitude determines the investment decision for biogas, albeit to a lesser extent than economic factors. The attitude of farmers also plays a critical role in the willingness to plant SRCs (Warren et al., 2016). Hence, Hypothesis 7 is formulated:

H7: A favorable attitude towards agricultural wood positively influences the decision of farmers to plant an ACS as EFA.

The risk appetite of a farmer likewise determines the decision behavior (Granoszewski et al., 2011). Riskaverse decision-makers tend to delay the implementation of operational investments (Sauer and Zilberman, 2009). Vollmer et al. (2015) show that the probability of an investment being made too late increases with rising risk aversion. The stronger the risk aversion is, the later investments are made (Viscusi et al., 2011) and growth strategies implemented (Inderhees, 2007), and the more defensive the decision behavior of the farmers (Schaper et al., 2010). Thus, Hypothesis 8 is stated as follows:

H8: The more risk averse a farmer is, the lower the willingness to plant an ACS as EFA.

Investment behavior is partly determined by management characteristics such as the experience or knowledge of the farm manager (Voss et al., 2008). Jonsson et al. (2011) identify experience as being a key determinant in the decision to plant energy crops. The experience of the farmer is also a significant factor in the decision to use manure solids as fermentation substrates (Kröger et al., 2016b). Sauer and Zilberman (2009) were also able to determine a positive influence of experience on the willingness of farmers to invest. In the view of farmers surveyed by Skodawessely and Pretzsch (2009), the cultivation of wood fuel is primarily impeded by a lack of knowledge and experience with SRCs. In light of this, Hypothesis 9 is composed:

H9: The more experience farmers have with agricultural wood, the greater the willingness to plant an ACS as EFA.

\subsection{Social influence}

The contacts of a decision-maker can have an important influence on their behavior. Behavior is particularly affected by how the decision-maker believes their own action is assessed by the social environment if the decision is socially visible (Fishbein and Ajzen, 1975). Farmers represent important members of a village community (Retter et al., 2002). The social environment in the form of family, friends, colleagues and local residents thus exerts an influence on the decision of farmers (Solano et al., 2003; Zimmermann, 2003). Granoszewski et al. (2009) confirm that the position of the respective rural environment is also relevant for decisions regarding investments in biogas plants. Conversely, the opinion of occupational peers and advisors are less important for the decision to invest, according to their study (Granoszewski et al., 2009). Information about the decisions of others has a strong influence on one's own investment decision (Viscusi 
et al., 2011). Skodawessely et al. (2009) determine that the assessment of SRCs by nature conservation associations shapes public opinion on the planting of agricultural wood. This, in turn, affects the attitude and acceptance of farmers. The planting of SRCs - and thus farmers' investments into a kind of innovation (Rogers, 2003) - requires the acceptance of all stakeholder groups; this also applies to the establishment of alley cropping agricultural wood as EFAs. Consequently, Hypothesis 10 is drawn:

H10: The influence of the respective social environment affects the decision of farmers to plant an ACS as EFA.

\section{Material and methods}

\subsection{Study design and analysis methods}

In the first quarter of 2017, 238 managers of conventional farms were surveyed on their attitude towards planting agricultural wood by means of a standardised online questionnaire. To reach as many farmers as possible, various distribution channels ${ }^{3}$ were utilized. The link to the questionnaire could only be used once; this ensured that a farm manager could not participate in the survey multiple times.

In total, the questionnaire covered 140 variables. The statements of the questionnaire were predominantly measured using five-point Likert scales from -2 (totally disagree) to +2 (totally agree) (based on Kröger et al., 2016a). Only experience with agricultural wood had to be entered on a seven-point Likert scale, from 1 (no experience) to 7 (very much experience). Further characteristics were collected using open and nominally scaled questions. The questionnaire was designed based on extensive literature research, discussions with experts and own experience; it contained various questions on the attitudes of German farmers towards planting agricultural wood in general and planting agricultural wood in an ACS as EFAs as well as on operations and social demography. Following a week-long preliminary test, the questionnaire was placed online from 30 January to 30 April 2017 using the Unipark program of the company Globalpark AG.

Data analysis was conducted with the use of the statistics program IBM Statistics 24 (IBM, Armonk, NY, USA). To obtain an initial overview of the sample, the sociodemographic data were analyzed on a univariate basis (Raab-Steiner and Benesch, 2008). An explorative factor analysis was subsequently conducted due to the range of variables that describe attitudes towards agricultural wood. By reducing the analysis to as few factors as possible in this manner, the individual factors could be interpreted more effectively and better explain the observed relationships between the variables (Backhaus et al., 2011; Bühl, 2010). For quality checking, the KMO value, Bartlett's test and subsequent reliability analysis were applied (Brosius, 2013). Multiple linear regression was then calculated as a next step based on the extracted factors and in consideration of further relevant variables (Section 2). The input variables were scaled at intervals; nominally scaled variables were separated into dummy variables. The coefficient of determination $\left(\mathrm{R}^{2}\right)$ was applied as the quality criterion for the regression model. In addition, all factors were examined for significance, a Durbin Watson test was calculated in order to be able to eliminate the autocorrelation of residuals, and the variables were checked for multicollinearity (Backhaus et al., 2011; Brosius, 2013).

\subsection{Sample description}

The sample includes 238 conventional farmers; $98.3 \%$ are male and $1.7 \%$ female. On average, the farmers are 44.9 years old and have 25.3 years of experience in farming. The sample is characterized by a very high level of professional education; $46.2 \%$ of the surveyed farmers have a university degree and $19.3 \%$

\footnotetext{
${ }^{3}$ All farms providing agricultural training in Germany that added their email addresses to the websites of the respective Chambers of Agriculture were contacted. Moreover, multiple farmers' associations, the specialist magazines Top Agrar and Profi, the Bayerische landwirtschaftliche Wochenblatt, the Landwirtschaftliche Zeitung Rheinland, the agricultural websites agrarticker.de and agrarheute.de, the federal association BioEnergie and the Lower Saxony Network for Renewable Resources sent the link to the questionnaire directly to their members, placed the link on their website or forwarded it onto members in their newsletter.
} 
are qualified as agricultural masters. The sample thus differs substantially from the overall population of all farmers, in which only $9.8 \%$ of farmers have a university degree (Destatis, 2011). In this sample, $89.1 \%$ of farms are managed as main occupations. The surveyed farmers manage 309.0 hectares on average, of which on average 259.7 hectares are arable land, 45.2 hectares are permanent grassland and 4.1 hectares are for permanent crops. The farm size thus lies significantly above the average of the basic population -60.5 hectares of agriculturally used land per farm (Destatis, 2017). The proportion leased land of farms lies at around $47.9 \%$ on average and therefore differs from the German average of $58.7 \%$ (Destatis, 2017). The soil score varies in this sample from 3 to 90 ; the predominant type of soil stated by the farmers was sandy loam (25.6\%), followed by heavy loam (19.7\%) and loamy sand (19.3\%). The greatest proportion of farms is located in southern Germany (30.7\%); $27.7 \%$ of farms are located in northern Germany and 24.8\% in western Germany. Eastern Germany is the location of $16.8 \%$ of surveyed farms. Conversely, in the overall population, almost half of farms are found in southern Germany (47.6\%), a quarter in western Germany $(25.0 \%), 18.4 \%$ in northern Germany and 9.0\% in eastern Germany (Destatis, 2017).

\section{Findings of the empirical survey}

Conventional farmers tend not to want to plant ACS as EFAs on their fields in the near future $(\mu=-1,29)$, as shown in Figure 1. 82.8\% of farm managers reject the planting of ACS as EFAs, $10.5 \%$ are undecided, and $6.7 \%$ intend to plant ACS as EFAs. In contrast, the surveyed farmers are undecided whether they consider the planting of ACS to be expedient as part of greening $(\mu=-0,12)$ and whether they would decide in favor of this if it were suitably profitable $(\mu=0,27) .41 .2 \%$ of farm managers assess ACS to be not expedient as EFA, $21.4 \%$ are undecided, and $37.4 \%$ consider ACS to be expedient as part of greening. If the growing of ACS is profitable as EFA, $47.5 \%$ of farmers would opt in favor of planting, $22.7 \%$ are undecided, and 29.8\% would not be convinced of planting ACS as EFA even if it were profitable to do so.

The willingness of German farmers to plant ACS as EFAs is presumably conditional upon various factors (Section 2). In order to achieve a dimensional reduction of the range of possible variables relating to the attitudes of farmers, an explorative factor analysis was first conducted. The principal component analysis was used as extraction method and varimax rotation applied. To optimize the factor solution, all variables that were loaded on more than one factor, as well as variables with insufficient commonality $(\leq 0.5)$, were removed (Brosius, 2013).

Five factors could be determined which consist of 19 variables. The tests for assessing the quality of the factor analysis confirm that the resulting factors meet all standard quality requirements. The stated overall variance of the factors is acceptable at $64.4 \%$. The KMO value amounts to 0.861 , whereby the measurement is considered well suited for the sample suitability. The correlation coefficients in the overall population are

$$
\text { - totally disagree } \quad \square \text { disagree } \quad \text { undecided } \quad \text { agree totally agree }
$$

I intend to grow alley cropping agricultural wood as EFAs in the near future.

I consider the growing of alley cropping agricultural wood as EFAs to be expedient as part of greening.

If it were profitable to grow alley cropping agricultural wood as EFAs, I would grow agricultural wood.

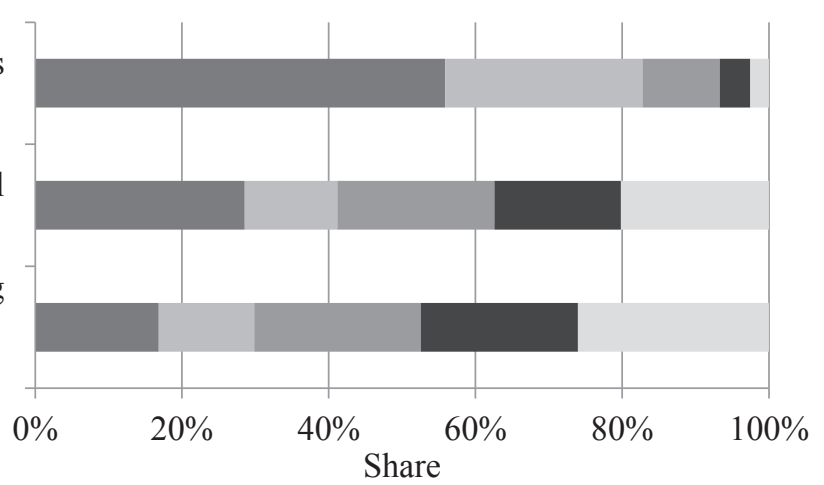

Figure 1. Frequency distribution for the willingness to plant alley cropping agricultural wood as EFAs. 
not zero, as Bartlett's test for sphericity verifies (Brosius, 2013). Furthermore, the reliability analysis shows that the internal consistency of the factors is sufficiently high. For all factors, Cronbach's alpha lies above the minimum value of 0.6 stipulated in the literature (Backhaus et al., 2011; Bühl, 2010). The results of the factor analysis can be seen in Table 1 .

The first factor comprises three variables that enable conclusions to be drawn regarding the interest of surveyed farmers in growing agricultural wood. A high level of agreement with the statements generally indicates a high degree of information about agricultural wood and its cultivation. The second factor consists of three variables that indicate the assessment of respondents regarding the operational advantages of growing agricultural wood. If this factor has a high value, the farm managers hold the view that agricultural wood can offer advantages to the whole farm operation. The third factor comprising five variables is concerned with the opportunities of growing agricultural wood, which have a direct impact on the field. Agreement with these statements shows that respondents can imagine benefits to the field as a result of growing agricultural wood. The fourth factor encompasses four variables and deals with the possible cultivation risks of growing agricultural wood. This factor is expressed as a high value if the respondents believe that various risks would render the cultivation of agricultural wood unattractive for them. The fifth factor contains four variables

Table 1. Results of the factor analysis. ${ }^{1}$

\section{Factors with statements}

Factor loading

Factor 1: Interest in agricultural wood (C. $\alpha=0.741$; share of total explained variance: $11.1 \%)$

I have discussed agricultural wood with colleagues who cultivate agricultural wood. 0.836

I have informed myself about the growing of agricultural wood (online, specialist magazines, 0.802 presentation, fair, etc.).

My farm already cultivates agricultural wood.

Factor 2: Advantages for the farm operation $(\mathrm{C} . \alpha=0.834$; share of total explained variance: $12.4 \%$ )

Growing agricultural wood enables the spreading of risk for my farm.

0.819

Growing agricultural wood offers development opportunities for my farm.

0.777

The soil nutrient content of a field can be improved by growing agricultural wood.

0.731

Factor 3: Advantages on the field (C. $\alpha=0.821$; share of total explained variance: $15.2 \%$ )

Alley cropping agricultural wood reduces the risk of erosion on adjoining farmland.

0.758

Agricultural wood can enhance the landscape, particularly in cleared agricultural landscapes.

0.753

Growing agricultural wood can improve biodiversity in agrarian landscapes.

0.695

Two land use claims (food and bioenergy) can be realized by growing alley cropping

0.689

agricultural wood.

Agricultural wood provides a practical opportunity of complying with the greening

0.541

requirements of the Common Agricultural Policy (CAP).

Factor 4: Cultivation risks (C. $\alpha=0.685$; share of total explained variance: $11.1 \%$ )

The high investment costs prevent me from growing agricultural wood.

0.749

The greening subsidy only compensates for a fraction of the higher effort required to harvest

0.727 agricultural crops between strips of agricultural wood.

The costs of alley cropping agricultural wood are very high.

0.685

The irregular cash flows during the production process make agricultural wood unattractive $\quad 0.683$ for me.

Factor 5: Publicity effect (C. $\alpha=0.833$; share of total explained variance: $14.6 \%$ )

The growing of alley cropping agricultural wood as EFAs improves my public image.

Growing agricultural wood improves the image of conventional farming.

0.784

The growing of agricultural wood for complying with greening requirements would be

0.767

supported by the local residents in my village.

Farmers who plant agricultural wood are considered to be innovative.

0.744

Principal component analysis; varimax rotation; total explained variance: $64.4 \%$; KMO =0.861; C. $\alpha=$ Cronbach's alpha. 
that - in the case of the agreement of the respondents - attests to a positive effect of cultivating agricultural wood on the public image.

In the next step, a regression analysis is performed to show which of the examined factors have a linkage to the intention of farmers to grow ACS as EFAs in the near future. In addition to the generated factors, the calculation includes further variables, some of which had to be coded as dummy variables due to their scaling. The statistical model of regression is significant and accounts for $36.7 \%$ of the total variance. The autocorrelation of residuals was checked by means of a Durbin Watson test. As the value for this regression model is almost two (at 1.899), an autocorrelation of residuals can be ruled out (Backhaus et al., 2011; Bühl, 2010). Moreover, there is no multicollinearity since the variance inflation factor values lie significantly below ten (Bowerman and O'Connell, 1990). The regression model thus satisfies the standard quality tests. The result of the regression analysis can be seen in Table 2 .

The variables that are included in the regression model are associated with the areas 'personal criteria', with the attitudes and experience of farmers relating to agricultural wood, 'operational criteria' as well as 'social

Table 2. Result of the regression analysis. ${ }^{1}$

\begin{tabular}{|c|c|c|c|}
\hline Independent variable & $\begin{array}{l}\text { Standardised } \\
\text { regression } \\
\text { coefficient beta }\end{array}$ & Significance & $\begin{array}{l}\text { Variance } \\
\text { inflation } \\
\text { factor }\end{array}$ \\
\hline \multicolumn{4}{|l|}{ Personal criteria } \\
\hline \multicolumn{4}{|l|}{ Criteria on attitudes towards agricultural wood } \\
\hline Factor 2: advantages for the farm operation & 0.282 & $0.000 * * *$ & 1.684 \\
\hline Factor 3: advantages on the field & 0.212 & $0.001 * * *$ & 1.362 \\
\hline Factor 1: interest in agricultural wood & 0.155 & 0.099 & 3.291 \\
\hline Factor 5: publicity effect & 0.118 & 0.060 & 1.468 \\
\hline Factor 4: cultivation risks & -0.118 & $0.025^{*}$ & 1.027 \\
\hline \multicolumn{4}{|l|}{ Experience with agricultural wood } \\
\hline Please rate your experience with agricultural wood using the scale ${ }^{4}$ & 0.045 & 0.614 & 3.020 \\
\hline \multicolumn{4}{|l|}{ Further personality criteria } \\
\hline I am prepared to take on risks in order to advance my farm business ${ }^{3}$ & 0.020 & 0.715 & 1.146 \\
\hline Agricultural training ${ }^{2}$ & -0.116 & $0.036^{*}$ & 1.142 \\
\hline Age of the farm manager ${ }^{5}$ & -0.022 & 0.674 & 1.064 \\
\hline \multicolumn{4}{|l|}{ Operational criteria } \\
\hline I would like to expand my farm business ${ }^{3}$ & 0.098 & 0.087 & 1.222 \\
\hline The long-term solvency of my farm business is secured ${ }^{3}$ & 0.022 & 0.698 & 1.168 \\
\hline Annual volume of precipitation 6 & -0.144 & $0.011 *$ & 1.192 \\
\hline Farm size of at least 1000 hectares $^{2}$ & -0.072 & 0.188 & 1.110 \\
\hline Part-time farms ${ }^{2}$ & -0.062 & 0.269 & 1.169 \\
\hline \multicolumn{4}{|l|}{ Social influence } \\
\hline $\begin{array}{l}\text { The decision to grow agricultural wood would be supported in my } \\
\text { farm business (family, partner, etc.) }\end{array}$ & 0.209 & $0.006^{* *}$ & 2.169 \\
\hline $\begin{array}{l}{ }^{1} \text { Dependent variable: 'I intend to grow alley cropping system as ecological foc } \\
\text { enter; corr. } \mathrm{R}^{2}=0.367 ; \mathrm{F}=10.171 ; P=0.000 ; \mathrm{n}=238 \text {; significance: } * P<0.05 \text {, } \\
{ }^{2} \text { Dummy variables; } \\
{ }^{3} \text { Scale from }+2=\text { totally agree to }-2=\text { totally disagree; } \\
{ }^{4} \text { Scale from } 1=\text { no experience to } 7=\text { very much experience; } \\
{ }^{5} \text { In years; } \\
6 \text { In millimeter. }\end{array}$ & $\begin{array}{l}\text { cus areas on my fiel } \\
* * P<0.01, * * * P<0\end{array}$ & $\begin{array}{l}\text { Is in the near futu } \\
01 .\end{array}$ & ire'; method: \\
\hline
\end{tabular}


influence'. It becomes evident that the factors initially generated from the area 'attitude towards agricultural wood' have a linkage to the intention to grow ACS as EFAs. In particular, the factors 'advantages for the farm operation' and 'advantages on the field' represent positive linkages to the cultivation decision of ACS as EFAs. The factor 'cultivation risks', in contrast, has a significantly negative effect on the decision to grow ACS as EFAs. All the factors initially generated for the attitudes towards agricultural wood could, therefore, be included in the regression analysis. Even if not all the factors are significant, they still invariably have a linkage to the intention of farmers to grow ACS as EFAs in the near future.

The level of training of the respondents likewise has a significant linkage to the planting decision. Farm managers with agricultural training as their highest educational qualification tend to be less willing to grow ACS as EFAs. Of the operational criteria, only the 'annual volume of precipitation' has a significant linkage to the growing decisions of farmers. The lower the annual volume of precipitation is, the more farmers tend towards cultivating ACS as EFAs. Moreover, it was possible to demonstrate a significant effect of 'social influence' on the decision to grow ACS as EFAs. If farm managers are convinced that their decision to cultivate agricultural wood will be supported by their social environment, this will tend to have a positive effect on their actual planting decision. Hypotheses H4, H6, H7 and H10 can thus be accepted.

Contrary to the expectations derived from the literature, the operational criteria 'farm size', 'type of employment' and 'economic situation' as well as the personal criteria 'age', 'risk appetite' and 'experience' could not be shown to be significant factors on the willingness to cultivate ACS as EFAs. With the exception of the criterion 'type of employment', however, the signs do point in the presumed direction. Nonetheless, hypotheses H1, H2, H3, H5, H8 and $\mathrm{H} 9$ must be discarded.

\section{Discussion}

Overall, the surveyed farmers tend to reject the growing of ACS for the provision of EFAs. Thus, the results of prior studies have been confirmed regarding the cultivation of agricultural wood. This rather negative attitude was already demonstrated in studies on the acceptance of SRCs in the United Kingdom (Glithero et al., 2013; Warren et al., 2016). In Germany, too, farmers have a critical stance towards the cultivation of SRCs due to the lack of knowledge and experience relating to SRCs as well as due to the long-term capital and land commitment (Skodawessely et al., 2008). Boll et al. (2015), however, were able to show that German farmers demonstrate a general willingness to cultivate SRCs, although only $10.5 \%$ of their respondents were already involved in SRC cultivation. However, so far, no studies exist which examine the attitudes or acceptance of agricultural wood in the context of providing EFAs in the context of the EU CAP.

The aim of this study was therefore to analyze the factors affecting the willingness of German farmers to grow ACS as EFAs. The acceptance of agricultural wood is of key importance for the successful establishment of this EFA measure. There have so far been few studies that examine the acceptance of agricultural wood cultivation generally; none of these studies, however, refer to greening. A contribution towards closing important research gaps in light of the increasing greening of agricultural policy can thus be achieved with this investigation.

The regression analysis shows that both operational and personal factors, as well as the social environment, determine the willingness to grow ACS as EFAs. The combined effect of these linkages (already determined in previous studies) on the decision behavior of farmers can thus be confirmed (Burton, 2004).

Skodawessely and Pretzsch (2009), as well as Wróbel et al. (2009), already confirmed that the location characteristics exert an influence on the acceptance of agricultural wood. Likewise, in this paper, the location conditions in the form of the precipitation volume determine the willingness to grow agricultural wood as EFAs. The lower the volume of precipitation is, the greater the willingness to cultivate ACS as EFAs. 
The professional level of education proves to be another factor that has a linkage to the growing decision. Farm managers with agricultural training tend to reject the cultivation of ACS as EFAs. This leads to the assumption that the willingness to grow agricultural wood increases with a higher level of professional education in the form of an agricultural master qualification or agricultural degree. This corresponds with previous studies, according to which the investment threshold of farmers reduces with a rising level of professional education, for example (Gardebroek and Oude Lansink, 2004; Sauer and Zilberman, 2009). However, the level of professional education presumably also has a linkage to other factors of the growing decision.

As previously shown by Warren et al. (2016) regarding the acceptance of SRCs in the United Kingdom, the attitude towards growing agricultural wood represents another personal factor. The greater the agricultural and operational advantages arising from agricultural wood, as well as the interest in agricultural wood, are judged and the lower the cultivation risks of growing agricultural wood are estimated, i.e. the more strongly the farm managers hold a positive attitude towards agricultural wood, the greater the acceptance of ACS for the provision of EFAs. In this respect, this paper also illustrates the long-postulated general importance of attitudes for the behavioral intentions of decision-makers (Fishbein and Ajzen, 1975).

The linkage between the social environment and the decision-maker most strongly co-determines the acceptance of agricultural wood as EFAs. This is likewise substantiated by previous studies (Granozewski et al., 2009; Solano et al., 2003; Zimmermann, 2003). If farm dependents (such as the partner or family) support the decision, the willingness to cultivate ACS as EFAs increases.

Although further determinants are shown to have an influence on the farmers' acceptance in various studies (Section 2), no significant effect on the willingness to cultivate ACS as EFAs could be demonstrated for these factors in this paper. This is possibly due to limitations exhibited by this paper - as it is the case with most experimental investigations - which should have been taken into consideration when interpreting the findings. The sample in this investigation is therefore not representative for the overall population of conventional farmers in Germany due to the insufficient size of the sample and its composition. A significantly above-average level of professional education and above-average farm sizes are overrepresented in the sample. However, as the decision behavior of farmers is influenced by operational and sociodemographic characteristics (e.g. Boll et al., 2015; Borris et al., 2013; Granoszewski et al., 2011; Jonsson et al., 2011; Sauer and Zilberman, 2009; Warren et al., 2016; Wróbel et al., 2009), the inadequate representativity can lead to distortions in the response behavior of farmers. In addition, the survey method, as well as the selective inclusion of respondents due to the distribution media, may have contributed to further distortions. The allocation of attractive incentives and the definition of a quota regarding sociodemographic and operational characteristics could reduce these distortions in future studies. It should also be noted that the willingness of the farmers concerns expressed intentions and not actual actions. Due to the high number of respondents in the sample, it is nonetheless possible to derive important hints from the results for the promotion of growing ACS as EFAs which are also relevant for the overall population - in any case, however, at least for the group of larger farms.

\section{Conclusions}

Only little spatial relevancy under the current CAP framework does not automatically imply that it is not relevant for the future. The acceptance of agricultural wood is a progress taking many years due to certain barriers and sceptics. Nevertheless, starting points for promoting the cultivation of agricultural wood as EFAs can be found, on the one hand, in the dissemination of knowledge regarding agricultural wood cultivation and, on the other hand, in the improvement of greening framework conditions. The knowledge of farmers regarding agricultural wood cultivation could be improved by means of intensive publicity work and the provision of advisory services. An improved level of knowledge regarding the benefits of growing agricultural wood and the associated reduction of concerns relating to cultivation risks could help facilitate a more positive attitude of farmers, which could substantially increase the acceptance of agricultural wood 
as EFAs. Moreover, advisory services particularly for farms in locations with marginal yields could raise the attractiveness of agricultural wood. The framework conditions of greening should be improved by increasing the weighting factor for short-rotation coppices as EFAs to better reflect the ecological value of agricultural wood as well as to raise the attractiveness of this form of EFA. Profit maximization is not the only business motivation; however, in order to secure acceptance of new and unknown production systems particularly, strong financial incentives are required (Warren et al., 2016) which would be provided as a result of a higher weighting factor based on the study results. Furthermore, the minimum area of short-rotation coppices should be repealed. As noted by Drittler and Theuvsen (2017), strips of agricultural wood are not suitable as EFAs in all regions in Germany with a minimum area of 0.3 hectares due to highly varied field sizes regionally. It would also be important to ensure that political greening requirements have a long-term nature, such that farmers can be provided the necessary planning security for cultivation decisions, which are likewise long-term in nature due to the production cycle of agricultural wood. To identify further starting points for promoting agricultural wood cultivation as EFAs, future studies should more closely examine the attitude of farmers towards ACS as EFAs. The analysis of frequencies also indicates that farmers should not be considered to be a homogenous group with respect to their attitudes towards agricultural wood as EFAs. By identifying target groups (such as with the use of a cluster analysis), a step could be taken towards developing a differentiated picture of the willingness of German farmers to plant ACS as EFAs. The results could then be used to derive further measures for increasing the acceptance of agricultural wood as EFAs among farmers. It is also recommended to investigate the attractiveness of agricultural wood compared to other EFA measures in future studies.

Although based on the current CAP framework, the empirical findings of this study have also interesting implications for the new CAP system to be implemented after 2020. The idea of greening will be replaced and extended by the new system of conditionality and eco-schemes. The new conditionality is a mandatory but more flexible approach which will link farmers' income support to more environment- and climatefriendly farming practices. Eco-schemes which are mandatory for member states but voluntary for farmers will help to increase the environmental effect of first pillar payments. Against this background, insights into the determinants of farmer's decision to grow ACSs can provide meaningful input for a proper design of new conditionality and eco-schemes as vital parts of the new green architecture of the CAP.

\section{Acknowledgements}

This work is supported by the Deutsche Bundesstiftung Umwelt (DBU). The authors express their gratitude to the DBU for the financial support. We also acknowledge support by the German Research Foundation and the Open Access Publication Funds of the Goettingen University.

\section{References}

Adesina, A.A., D. Mbila, G.B. Nkamleu and D. Endamana. 2000. Econometric analysis of the determinants of adoption of alley farming by farmers in the forest zone of southwest Cameroon. Agriculture, Ecosystems and Environment 80: 255-265. https://doi.org/10.1023/A:1020556132073

Anderson, S.H., R.P. Udawatta, T. Seobi and H.E. Garrett. 2009. Soil water content and infiltration in agroforestry buffer strips. Agroforestry Systems 75: 5-16. https://doi.org/10.1007/s10457-008-9128-3

Austin, E.J., J. Willock, I.J. Deary, G.J. Gibson, J.B. Dent, G. Edwards-Jones, O. Morgan, R. Grieve and A. Sutherland. 1998. Empirical models of farmer behaviour using psychological, social and economic variables. Part I: linear modelling. Agricultural Systems 58(2): 203-224. https://doi.org/10.1016/ S0308-521X(98)00066-3

Backhaus, K., E. Erichson, W. Plinke and R. Weiber. 2011. Multivariate Analysemethoden - Eine anwenderorientierte Einführung. Vol. 13. Springer, Berlin, Germany.

Barham, L.B., J.D. Foltz, D. Jackson-Smith and S. Moon. 2004. The dynamics of agricultural biotechnology adoption: lessons from rBST use in Wisconsin, 1994-2001. American Journal of Agricultural Economics 86: 61-72. https://doi.org/10.1111/j.0092-5853.2004.00562.x 
Bärwolff, M., A. Vetter, C. Böhm, J. Hoffmann and C. Schmidt. 2011. Was bringen Streifen-KUP? Energie Pflanzen 2: 9-11.

Bärwolff, M., G. Reinhold, C. Fürstenau, T. Graf, L. Jung and A. Vetter. 2013. Gewässerrandstreifen als Kurzumtriebsplantagen oder Agroforstsysteme. Umweltbundesamt, Dessau-Roßlau, Germany. Available at: https://tinyurl.com/y8v39v6o

Beer, L. and L. Theuvsen. 2019. Conventional German farmers' attitudes towards agricultural wood and their willingness to plant an alley cropping system as an ecological focus area: a cluster analysis. Biomass and Bioenergy 125: 63-69.

Boll, T., F. Neubert, K. Zimmermann and A. Bergfeld. 2015. Decision criteria and implementation strategies for short rotation coppice in Germany from the perspective of stakeholders. In: D.B. Manning, A. Bemmann, M. Bredemeier, N. Lamersdorf and C. Ammer (eds.) Bioenergy from dendromass for the sustainable development of rural areas. Wiley-VCH, Weinheim, Germany, pp. 331-346.

Borremans, L., B. Reubens, B. Van Gils, D. Baeyens, C. Vandevelde and E. Wauters. 2016. A sociopsychological analysis of agroforestry adoption in Flanders: understanding the discrepancy between conceptual opportunities and actual implementation. Agroecology and Sustainable Food Systems 40(9): 10081036. https://doi.org/10.1080/21683565.2016.1204643

Borris, J. and S. Maart-Nölck. 2013. Investition in Biogas: ja oder nein? - Eine qualitative Analyse von Entscheidungsgründen landwirtschaftlicher Betriebsleiter. Berichte über Landwirtschaft 91(1): 1-23. http://dx.doi.org/10.12767/buel.v91i1.17.g57

Bowerman, B.L. and R.T. O'Connell. 1990. Linear statistical models: an applied approach. Vol. 2. Belmont, Duxbury, USA.

Breen, J., D. Clancy, B. Moran and F. Thorne. 2009. Modelling the potential supply of energy crops in Ireland: results from a probit model examining the factors affecting willingness to adopt. The Rural Economy Research Centre - Working Paper Series 09-WP-RE-05.

Brosius, F. 2013. SPSS 21. Mitp, Heidelberg, Germany.

Bühl, A. 2010. SPSS 18: Einführung in die moderne Datenanalyse. Vol. 13. Pearson, Munich, Germany.

Bund für Umwelt und Naturschutz Deutschland e.V., (BUND). 2010. Kurzumtriebsplantagen für die Energieholzgewinnung - Chancen und Risiken. BUNDpositionen. BUND, Berlin, Germany. Available at: https://tinyurl.com/ydd9reme

Bundesministerium für Ernährung und Landwirtschaft (BMEL). 2015a. Grundzüge der Gemeinsamen Agrarpolitik (GAP) und ihrer Umsetzung in Deutschland. BMEL, Bonn / Berlin, Germany. Available at: http://www.bmel.de/DE/Landwirtschaft/Agrarpolitik/_Texte/GAP-NationaleUmsetzung.html

Bundesministerium für Ernährung und Landwirtschaft (BMEL). 2015b. Umsetzung der EU-Agrarreform in Deutschland, edition 2015. BMEL, Bonn, Germany.

Bundesministerium für Ernährung und Landwirtschaft (BMEL). 2015c. Antwort der Bundesregierung auf die Kleine Anfrage der Abgeordneten Dr. Kirsten Tackmann, Caren Lay, Herbert Behrens, weiterer Abgeordneter und der Fraktion Die Linke. Bundestag document No 18/6397. German Bundestag, Berlin, Germany.

Bundesministerium für Ernährung und Landwirtschaft (BMEL). 2016. Antwort der Bundesregierung auf die Kleine Anfrage der Abgeordneten Dr. Kirsten Tackmann, Caren Lay, Karin Binder, weiterer Abgeordneter und der Fraktion Die Linke. Bundestag document No 18/10569. German Bundestag, Berlin, Germany.

Bundesministerium für Ernährung und Landwirtschaft (BMEL). 2018. Antwort der Bundesregierung auf die Kleine Anfrage der Abgeordneten Dr. Kirsten Tackmann, Dr. Gesine Lötzsch, Lorenz Gösta Beutin, weiterer Abgeordneter und der Fraktion Die Linke, Bundestag document No 19/1037. German Bundestag, Berlin, Germany.

Burton, R.J.F. 2004. Reconceptualising the 'behavioural approach' in agricultural studies: a socio-psychological perspective. Journal of Rural Studies 20: 359-371. https://doi.org/10.1016/j.jrurstud.2003.12.001

Destatis. 2011. Land- und Forstwirtschaft, Fischerei: Landwirtschaftliche Berufsbildung der Betriebsleiter/ Geschäftsführer; Landwirtschaftszählung/Agrarstrukturerhebung 2010. Special series 3(1). Federal Statistical Office, Wiesbaden, Germany.

Destatis. 2017. Landwirtschaftliche Betriebe. Available at: https://tinyurl.com/ybf5mmne 
Deutschen Bundesstiftung Umwelt (DBU). 2010. Multifunktionale Bewertung von Agroforstsystemen. Final report. Steinbacher Druck, Osnabrück, Germany.

DLG. 2012. Kurzumtriebsplantagen - Anlage, Pflege, Ernte und Wertschöpfung. DLG-Merkblatt 371. Available at: https://tinyurl.com/ycpjvgnz

Drittler, L. and L. Theuvsen. 2017. Agrarholz als ökologische Vorrangfläche im Rahmen der Gemeinsamen Agrarpolitik. Berichte über Landwirtschaft 95(2): 1-20. http://dx.doi.org/10.12767/buel.v95i2.164.g344

Dziewiaty, K., P. Bernardy, R. Oppermann, F. Schöne and J. Gelhausen. 2013. Ökologische Vorrangflächen - Anforderungen an das Greening-Konzept aus avifaunistischer Sicht. Julius-Kühn-Archiv 442: 126-137. https://doi.org/10.5073/jka.2013.442.011

Edwards, W. 1954. The theory of decision making. Psychological Bulletin 51(4): 380-417. https://doi.apa. org/doi/10.1037/h0053870

Eichhorn, M.P., P. Paris, F. Herzog, L.D. Incoll, F. Liagre, K. Mantzanass, M. Mayus, G. Moreno, V.P. Papanastasis, D.J. Pilbeam, A. Pisanelli and C. Dupraz. 2006. Silvoarable systems in Europe - past, present and future prospects. Agroforestry Systems 67: 29-50. https://doi.org/10.1007/s10457-005$1111-7$

European Commission. 2013. Overview of CAP Reform 2014-2020. Agricultural policy perspectives brief No 5. EC, Brussels, Belgium. Available at: https://tinyurl.com/y996fwub

Feldwisch, N. 2011. Rahmenbedingungen und Strategien für einen an Umweltaspekten ausgerichteten Anbau der für Sachsen relevanten Energiepflanzen. Umweltgerechter Anbau von Energiepflanzen. Sächsisches Landesamt für Umwelt, Landwirtschaft und Geologie, Dresden, Germany.

Fishbein, M. and I. Ajzen. 1975. Belief, attitude, intention, and behavior: an introduction to theory and research. Addison-Wesley, Reading, MA, USA.

Gardebroek, C. and A.G.J.M. Oude Lansink. 2004. Farm-specific adjustment costs in Dutch pig farming. Journal of Agricultural Economics 55(1): 3-24. https://doi.org/10.1111/j.1477-9552.2004.tb00076.x

Glithero, N.J., P. Wilson and S.J. Ramsden. 2013. Prospects for arable farm uptake of short rotation coppice willow and miscanthus in England. Applied Energy 107: 209-218. https://doi.org/10.1016/j. apenergy.2013.02.032

Gold, J.I. and M.N. Shadlen. 2007. The neural basis of decision making. Annual Review of Neuroscience 30: 535-574. https://doi.org/10.1146/annurev.neuro.29.051605.113038

Granoszewski, K., A. Spiller, C. Reise and O. Mußhoff. 2011. Die Diffusion regenerativer Energien in der deutschen Landwirtschaft - Investitionsverhalten in einem politisch induzierten Markt. $10^{\text {th }}$ International Conference Marketing Trends, Paris, France.

Granoszewski, K., C. Reise, A. Spiller and O. Mußhoff. 2009. Entscheidungsverhalten landwirtschaftlicher Betriebsleiter bei Bioenergie-Investitionen: erste Ergebnisse einer empirischen Untersuchung. Discussion paper No 0911. Department for Agricultural Economics and Rural Development, University of Goettingen, Goettingen, Germany.

Grünewald, H. and T. Reeg. 2009. Überblick über den Stand der Forschung zu Agroforstsystemen in Deutschland. In: T. Reeg, A. Bemmann, W. Konold, D. Murach and H. Spiecker (eds.) Anbau und Nutzung von Bäumen auf landwirtschaftlichen Flächen. Wiley-VCH, Weinheim, Germany, pp. 233-240.

Heise, H. 2017. Tierwohl in der Nutztierhaltung: Eine Stakeholder-Analyse. Dissertation, University of Goettingen, Goettingen, Germany.

Henke, S. and L. Theuvsen. 2014. SLCA: Regional differenzierte Bewertung von Biogasanlagen und Kurzumtriebsplantagen. In: M. Eder, F. Sinabell and T. Stern (eds.) Jahrbuch der Österreichischen Gesellschaft für Agrarökonomie. Vol. 23. Facultas, Wien, Austria, pp. 81-90.

Herbes, C., E. Jirka, J.P. Braun and K. Pukall. 2014. Der gesellschaftliche Diskurs um den „Maisdeckel’ vor und nach der Novelle des Erneuerbare-Energien-Gesetzes (EEG) 2012. GAIA 23(2): 100-108. https://doi.org/10.14512/gaia.23.2.7

Holst, G.S., A. März. and O. Mußhoff. 2016. Experimentelle Untersuchung der Optimalität von Investitionsentscheidungen. Schmalenbachs Zeitschrift für betriebswirtschaftliche Forschung 68: 167-192. https://doi.org/10.1007/s41471-016-0012-y

Ilbery, B.W. 1978. Agricultural decision-making: a behavioural perspective. Progress in Human Geography 2(3): 448-466. https://doi.org/10.1177/030913257800200303 
Inderhees, P.G. 2007. Strategische Unternehmensführung landwirtschaftlicher Haupterwerbsbetriebe: Eine Untersuchung am Beispiel Nordrhein-Westfalens. Dissertation, University of Goettingen, Goettingen, Germany.

Jonsson, A.C., M. Ostwald, T. Asplund and V. Wibeck. 2011. Barriers to and drivers of the adoption of energy crops by Swedish farmers: an empirical study. World Renewable Energy Congress, Linköping, Sweden.

Kahneman, D. and A. Tversky. 1979. Prospect theory: an analysis of decision under risk. Econometrica 47(2): 263-292. https://www.jstor.org/stable/1914185

Klabunde, A. 2016. Kurzumtriebsplantagen: Energielieferanten mit Zukunft. Available at: https://www.gabot. de/ansicht/kurzumtriebsplantagen-energielieferanten-mit-zukunft-248945.html

Kröger, R., J.R. Konerding and L. Theuvsen. 2016a. Güllefeststoffe als Gärsubstrat: Wird die Kluft im Diffusionsprozess übersprungen? In: R. Kühl, J. Aurbacher, R. Herrmann, E.-A. Nuppenau and M. Schmitz (eds.) Perspektiven für die Agrar- und Ernährungswirtschaft nach der Liberalisierung. Schriften der Gesellschaft für Wirtschafts- und Sozialwissenschaften des Landbaus, Berlin, Germany, pp. 93-104.

Kröger, R., J.R. Konerding and L. Theuvsen. 2016b. Identifikation von Einflussfaktoren auf die Nutzung von Güllefeststoffen als Gärsubstrat in Biogasanlagen. German Journal of Agricultural Economics 65(2): 112-131.

Lamerre, J., K.-U. Schwarz, M. Langhof, G. von Wühlisch and J.-M. Greef. 2015. Productivity of poplar short rotation coppice in an alley-cropping agroforestry system. Agroforestry Systems 89(5): 933942. https://doi.org/10.1007/s10457-015-9825-7

Müller, J. 2017. Entscheidungsverhalten bei komplexen Problemen: Die Sortenwahl bei Winterweizen. Dissertation, University of Giessen, Giessen, Germany.

Neubert, F.P., T. Boll, K. Zimmermann and A. Bergfeld. 2013. Chancen und Hemmnisse von Kurzumtriebsplantagen. AFZ-Der Wald 4: 4-6.

Nitsch, H., N. Röder, R. Oppermann, S. Baum and J. Schmarek. 2016. Naturschutzfachliche Ausgestaltung von Ökologischen Vorrangflächen. IflS, Frankfurt am Main, Germany.

Paulrud, S. and T. Laitila. 2010. Farmers' attitude about growing energy crops. A choice experiment approach. Biomass and Bioenergy 34(12): 1770-1779. https://doi.org/10.1016/j.biombioe.2010.07.007

Peters, W. 2012. Umsetzung von Naturschutzmaßnahmen bei der Anlage und Bewirtschaftung von KUP. Conference on fast-growing tree species, Freiberg, Germany.

Pfister, H.-R., H. Jungermann and K. Fischer. 2017. Die Psychologie der Entscheidung: Eine Einführung. Vol. 4. Springer, Berlin, Heidelberg, Germany.

Pisanelli, A., A. Perali and P. Paris. 2012. Potentialities and uncertainties of novel agroforestry systems in the European C.A.P.: farmers' and professionals' perspectives in Italy. Italian Journal of Forest and Mountain Environments 67(3): 289-297. https://doi.org/10.4129/ifm.2012.3.07

Raab-Steiner, E. and M. Benesch. 2008. Der Fragebogen - von der Forschungsidee zur SPSS/PASW Auswertung. UTB, Stuttgart, Germany.

Reeg, T. 2010. Moderne Agroforstsysteme mit Wertholzbäumen als Option der Landnutzung in Deutschland: Naturschutz, Landschaftsbild und Akzeptanz. Dissertation, University of Freiburg i. Brsg, Germany.

Retter, C., K. Stahr and H. Boland. 2002. Zur Rolle von Landwirten in dörflichen Kommunikationsnetzwerken. Berichte über Landwirtschaft 80(3): 446-467.

Rigueiro-Rodríguez, A., J. McAdam and M.R. Mosquera-Losada. 2009. Agroforestry in Europe - current status and future prospects. Springer, Berlin, Germany.

Rogers, E.M. 2003. Diffusion of innovations. Vol. 5. Free Press, New York, NY, USA.

Roos, A., H. Rosenqvist, E. Ling and B. Hektor. 2000. Farm-related factors influencing the adoption of short-rotation willow coppice production among Swedish farmers. Acta Agriculturae Scandinavica, Section B - Soil \& Plant Science 50(1): 28-34. https://doi.org/10.1080/090647100750014385

Sachverständigenrat für Umweltfragen (SRU). 2013. Die Reform der europäischen Agrarpolitik: Chancen für eine Neuausrichtung nutzen. Kommentar zur Umweltpolitik 11: 1-32.

Sauer, J. and D. Zilberman. 2009. Innovation behaviour at farm level-selection and identification. $83^{\text {th }}$ Annual Conference of the Agricultural Society, Dublin, Ireland. 
Savastano, S. and P.L. Scandizzo. 2009. Optimal farm size in an uncertain land market: the case of Kyrgyz Republic. Agricultural Economics 40: 745-758. https://doi.org/10.1111/j.1574-0862.2009.00412.x

Schaper, C. and L. Theuvsen. 2006. Die Zukunft erneuerbarer Energien: Eine SWOT-Analyse. In: Ländliche Betriebe und Agrarökonomie auf neuen Pfaden. Austrian Association for Agricultural Economics, Vienna, Austria, pp. 15-16.

Schaper, C., A. Spiller and L. Theuvsen. 2010. Risikoneigung und Risikoverhalten von Milcherzeugern: Eine Typologisierung. Yearbook of Socioeconomics in Agriculture 3: 157-193.

Sereke, F., M. Dobricki, J. Wilkes, A. Kaeser, A.R. Graves, E. Szerencsits and F. Herzog. 2016. Swiss farmers don't adopt agroforestry because they fear for their reputation. Agroforestry Systems 90: 385-394. https://doi.org/10.1007/s10457-015-9861-3

Simon, H.A. 1959. Theories of decision-making in economics and behavioral science. The American Economic Review 49(3): 253-283. https://www.jstor.org/stable/1809901

Skodawessely, C. and J. Pretzsch. 2009. Akzeptanz des Energieholzanbaus bei Landwirten. In: T. Reeg, A. Bemmann, W. Konold, D. Murach and H. Spiecker (eds.) Anbau und Nutzung von Bäumen auf landwirtschaftlichen Flächen. Wiley-VCH, Weinheim, Germany, pp. 217-226.

Skodawessely, C., T. Glaser, J. Retzsch and P.A. Schmidt. 2008. Einstellung von Landwirten und Naturschutzverbänden zu Kurzumtriebsplantagen. Schweizerische Zeitschrift für Forstwesen 159: 158-164. https://doi.org/10.3188/szf.2008.0158

Solano, C., H. León, E. Pérez and M. Herrero. 2003. The role of personal information sources on the decision-making process of Costa Rican dairy farmers. Agricultural Systems 76: 3-18. https://doi. org/10.1016/S0308-521X(02)00074-4

Spiecker, H., M. Brix and B. Bender. 2009. Neue Optionen für eine nachhaltige Landnutzung - Schlussbericht des Projekts ,,agroforst'. Bundesministerium für Bildung und Forschung, Bonn, Germany. Available at: https://www.agroforst.uni-freiburg.de/download/BMBF0330621_24-11-09.pdf

Swinton, S.M., N. Rector, G.P. Robertson, C.B. Jolejole-Foreman and F. Lupi. 2015. Farmer decisions about adopting environmentally beneficial practices. In: S.K. Hamilton, E. Doll and G.P. Robertson (eds.) The ecology of agricultural landscapes: long-term research on the path to sustainability. Oxford University Press, New York, NY, USA, pp. 340-359.

Viscusi, W.K., O.R. Phillips and S. Kroll. 2011. Risky investment decisions: how are individuals influenced by their groups? Journal of Risk and Uncertainty 43: 81-106. https://oi.org/10.1007/s11166-011-9123-3

Vollmer, E., D. Hermann and O. Mußhoff. 2015. Welche Faktoren beeinflussen die Optimalität der Investitionsentscheidungen konventioneller und ökologischer Schweinehalter? 55 Jahrestagung der Gesellschaft für Wirtschafts- und Sozialwissenschaften des Landbaues e.V., Giessen, Germany.

Voss, J., C. Schaper, A. Spiller and L. Theuvsen. 2008. Innovationsverhalten in der deutschen Landwirtschaft - Empirische Ergebnisse am Beispiel der Biogasnutzung. In: E. Berg, M. Hartmann, T. Heckelei, K. Holm-Müller and G. Schiefer (eds.) Risiken in der Agrar- und Ernährungswirtschaft und ihre Bewältigung. Schriften der Gesellschaft für Wirtschafts- und Sozialwissenschaften des Landbaues e.V. Vol.44, Muenster, Germany, pp. 379-391.

Warren, C.R., R. Burton, O. Buchanan and R.V. Birnie. 2016. Limited adoption of short rotation coppice: the role of farmers' socio-cultural identity in influencing practice. Journal of Rural Studies 45: 175183. https://doi.org/10.1016/j.jrurstud.2016.03.017

Weih, M., A. Karacic, H. Munkert, T. Verwijst and M. Diekmann. 2003. Influence of young poplar stands on floristic diversity in agricultural landscapes (Sweden). Basic and Applied Ecology 4: 149-156.

Willock, J., I.J. Deary, M.M. McGregor, A. Sutherland, G. Edwards-Jones, O. Morgan, B. Dent, R. Grieve, G. Gibson and E. Austin. 1999. Farmers' attitudes, objectives, behaviors, and personality traits: the Edinburgh study of decision making on farms. Journal of Vocational Behavior 54: 5-36. https://doi. org/10.1006/jvbe.1998.1642

Wirkner, R. 2012. Kurzumtriebsplantagen, Potenziale und Synergien. Deutsches Biomasseforschungszentrum gemeinnützige $\mathrm{GmbH}$, Leipzig, Germany. Available at: http://landratsamt-meissen.de/download/ Landratsamt/3Wirkner.pdf 
Wolbert-Haverkamp, M. 2012. Miscanthus und Pappelplantagen im Kurzumtrieb als Alternative zum klassischen Ackerbau - Eine Risikoanalyse mittels Monte-Carlo Simulation. Berichte über Landwirtschaft 90(2): 302-316.

Wróbel, A., J. Mosiej and M. Weih. 2009. Land availability analysis and social attitude aspects in relation to implementation and development of short' rotation forestry systems in Poland. Annals of Warsaw University of Life Sciences - SGGW, Land Reclamation 41(2): 153-166. https://doi.org/10.2478/ v10060-008-0058-6

Zehlius-Eckert, W. 2010. Agroforstwirtschaft in der europäischen Forschung - mit einem Schwerpunkt auf der ökologischen Nachhaltigkeit. Agrarholz 2010: Technical University of Munich, Munich, Germany. Available at: https://tinyurl.com/y9ky4zp3s

Zimmermann, M. 2003. Das Kaufverhalten von Landwirten im Bereich landwirtschaftlicher Investitionsgüter und die Auswirkung auf den Marketing-Mix landtechnischer Unternehmen. Dissertation, University of Goettingen, Goettingen, Germany.

Zschache, U., S. von Cramon-Taubadel and L. Theuvsen. 2009. Die öffentliche Auseinandersetzung über Bioenergie in den Massenmedien - Diskursanalytische Grundlagen und erste Ergebnisse. Discussion Paper No 0906, Department for Agricultural Economics and Rural Development, University of Goettingen, Goettingen, Germany. 
